\title{
Kaynaştırma eğitimi alan çocuklarda okul sağlığı hemşiresinin rolleri
}

\author{
Roles of school health nurses in children \\ with inculisive education
}

\author{
Selverhan Yurttutan, Naime Altay
}

Gazi Üniversitesi Sağlık Bilimleri Fakültesi, Hemşirelik Bölümü, Ankara, Turkey

\begin{abstract}
Özet
Özel gereksinimi olan çocuk, çeşitli nedenlerle bireysel ve gelişim özellikleri ile eğitim yeterlilikleri açısından akranlarından beklenilen düzeyden anlamlı farklııı gösteren çocuk olarak tanımlanmaktadır. Özel gereksinimli çocukların fiziksel, duygusal, sosyal ve eğitim gereksinimleri sağlıklı akranlarına göre farklıık göstermektedir. Özel gereksinimi olan çocuklara yönelik verilen eğitim hizmetlerinden biride kaynaştırma eğitimidir. Kaynaştırma eğitimine devam eden çocuklar okulda boşaltım ve hareket gereksinimini karşılayabilme, okula ulaşımı sağlama, ilaçlarını kullanabilme gibi fiziksel gereksinimlerini karşılamakta güçlük yaşayabilmektedir. Ayrıca arkadaşları ve öğretmenleri ile iletişim kurma, sosyal aktivitelere katılma ve akranları ile vakit geçirme gibi psikososyal gereksinimlerini karşılamada sorunlar yaşayabilmektedir. Kaynaştırma eğitimi alan çocukların ebeveynleri zamanlarının çoğunu okulda çocukları ile beraber geçirme, kendilerine zaman ayıramama, sosyal çevreden uzaklaşma gibi sorunlar yaşamaktadırlar. Bu çocukların ve ailelerin gereksinimlerinin karşılanması okul sağlığı hemşiresinin önemli rolleri arasındadır. Okul sağlığı hemşiresinin bakım verici, eğitici, araştırıcı, danışmanlık verici, karar verici, koruyucu ve savunucu olma rolleri bulunmaktadır. Özel gereksinimi olan çocukların ve ailelerinin bakım gereksinimlerinin hemşireler tarafından karşılanması, ailelerin bakım yükünü azaltması, çocuk ve ailenin yaşam kalitesinin artması açısından önemlidir. Bu derlemede kaynaştırma eğitimi alan çocukların ve ailelerinin gereksinimleri ve okul sağlığı hemşiresinin rolleri ele alınmıştır.
\end{abstract}

Anahtar Sözcükler: Kaynaştırma eğitimi; okul sağlığı hemşiresi; ozel bakım gereksinimli çocuk.

5 ocuklarda özel bakım gereksinimi, doğumda ya da daha sonra gelişebilen, uzun süreli bakım gerektiren, çocuk ve ailenin yaşamını olumsuz olarak etkileyen bir durumdur. Özel

\begin{abstract}
A child with a special needs is defined as a child who for a variety of reasons has individual and developmental characteristics and educational qualifications that differ significantly from the level expected from their peers. Physical, emotional, social and educational needs of children with special needs differ according to their healthy peers. One of the educational services for children with special needs is integration education. The children who continuing integration education may have difficulty doing their physical needs, such as defecation at school, movement needs, going to school, stepping stairs, and taking daily medicine by himself/herself. They can also experience problems in meeting psycho-social needs such as communicating with friends and teachers, participating in social activities in school and spending time with their peers. Parents of this kind of children often have problems as, unable to take their own special time, and isolation from social environment, which can reduce the quality of life of parents. Meeting the needs of these children and their families is one of the important roles of the school health nurse. The school health nurse has roles to be caring, educating, researching, counseling, decision making, protective and defensive. It is important for nurses to meet the care needs of children and their families who need special care, to reduce the care responsibilities of families, and to increase the quality of life for the children and the parents. In this review, the needs of inclusive children and their families and the role of the school health nurse have been addressed.
\end{abstract}

Keywords: Inclusive education; school health nurse; special care needs child.

bakım gereksinimi olan çocuk ve ailesinin fiziksel, duygusal ve psikososyal pek çok sorunla baş etmesi gerekmektedir. ${ }^{[1]}$ Özel bakım gereksinimi kavramı yerine zaman zaman engelli, özür- 
lü, sakat ve çürük gibi bazı terimler kullanılsa da günümüzde dünyada ve ülkemizde bireyleri etiketlemeden yapılan tanımların kullanılması önerilmektedir. Sıklıkla tercih edilen kavramlar: farklı gelişim gösteren çocuklar, özel gereksinimli çocuklar, özel eğitim gerektiren çocuklar, öğrenme farklıığı olan çocuklar, gelişim farklılığı olan çocuklar, özel gereksinimli bireylerdir. ${ }^{[2]}$ Milli Eğitim Bakanlığı Özel Eğitim Hizmetleri Yönetmeliği'nde (ÖEHY) özel gereksinimli birey, "çeşitli nedenlerle bireysel ve gelişim özellikleri ile eğitim yeterlilikleri açısından akranlarından beklenilen düzeyden anlamlı farklılık gösteren birey" olarak tanımlanmaktadır. ${ }^{[3]}$ Dünya Sağlık Araştırması (2011), sonuçlarında Dünyada 15 yaş ve üstünde engellilik ile yaşamak durumunda olan kişi sayısı 785 milyon (\%15.6) olarak belirtilmiştir. Küresel Hastalık Yükü çalışmasına göre (2011), bu sayı yaklaşık 975 milyon (\%19.2) olarak tahmin edilmektedir. [4] Ülkemizde ise, Türkiye Özürlüler Araştırması (2002) verilerine göre, engelli olan nüfusun toplam nüfus içindeki oranı $\% 12.29$ 'dur. 0-19 yaş aralığında engelli nüfusu \%8.78 olarak belirtilmektedir. ${ }^{[5]}$

Özel bakım gereksinimli çocuklar kavramı fiziksel, zihinsel, sosyal ya da duygusal gelişimsel alanlarda çeşitli sorunları ifade etmektedir. Özel gereksinimli çocuk ifadesi, öğrenme ve/veya davranış sorunları gösteren, bedensel ya da duygusal yetersizliği olan bireyleri olduğu kadar zihinsel olarak üstün ya da özel yetenekli çocukları da kapsamaktadır. ${ }^{[6]}$ Bu derlemede fiziksel, öğrenme, davranış ya da duygusal yetersizliği olan çocuklar ele alınmıştır.

Özel bakım gereksinimli çocukların fiziksel, duygusal, sosyal ve eğitim gereksinimleri sağlıklı akranlarına göre farklılık göstermektedir. Özel bakım gereksinimli çocukların normal gelişim gösteren akranları ile aynı ortamı paylaşmasının sosyal iletişim ve akademik başarının artmasında yararlı olduğu vurgulanmaktadır. ${ }^{[7,8]}$ Kaynaştırma eğitimi, okul çağı döneminde olan özel bakım gereksinimli çocukların normal gelişim gösteren akranları ile aynı ortamda olabilmelerini sağlayan bir eğitim hizmetidir. ${ }^{[9]}$ Özel bakım gereksinimli çocukların ve ailelerinin gereksinimlerinin belirlenmesi ve karşılanması çocukların sağlıklarının korunması, geliştirilmesi ve olası sorunların önlenmesi/azaltılması için oldukça önemlidir. Kaynaştırma eğitimi alan özel bakım gereksinimli çocukların ve ailelerinin gereksinimlerinin belirlenmesi ve karşılanması okul sağlığı hemşiresinin görevleri arasında yer almaktadır.

Bu derleme kaynaştırma eğitimi alan çocukların ve ailelerinin gereksinimlerini ve okul sağlığı hemşiresinin rollerini incelemek amacıyla hazırlanmıştır. Derlemenin kaynaştırma eğitimi alan çocukların ve ailelerinin bakımında rol alan hemşirelere yol gösterici olacağı, çocukların ve ailelerin gereksinimlerinin karşılanması ve dolayısıyla yaşam kalitelerinin artmasına katkı sağlayacağı düşünülmektedir. Derleme, 1) Özel bakım gereksinimli çocuklar ve kaynaştırma eğitimi, 2) Özel bakım gereksinimli çocuklar ve ailelerin kaynaştırma eğitiminde yaşadığı sorunlar ve 3) Kaynaştırma eğitimi alan çocuklarda okul sağlığı hemşiresinin rolleri konu başlıkları ile ele alınmıştır.

\section{Özel Bakım Gereksinimli Çocuklar ve Kaynaştırma Eğitimi}

Ülkemizde özel bakım gereksinimli çocuklara verilen eğitim hizmetlerinden biride kaynaştırma eğitimidir. Kaynaştırma eğitimi; özel eğitim gerektiren çocukların, yetersizliği olmayan akranları ile birlikte eğitim ve öğretimlerini, okul öncesi, ilköğretim, ortaöğretim ve yaygın eğitim kurumlarında sürdürmeleri esasına dayanan, destek eğitim hizmetlerinin sağlandığı özel eğitim uygulamalarıdır. ${ }^{[10]}$ Milli Eğitim Bakanlığına göre 20152016 eğitim öğretim yılında okul öncesi, ilkokul ve ortaokula kayıtlı toplam öğrenci sayısı 14.540 .399 kişidir. Bu öğrencilerin 202.541 'i ise kaynaştırma eğitimine devam etmektedir. ${ }^{[1]]}$

Kaynaştırma eğitiminin amacı; özel bakım gereksinimli çocuğa özgüven kazandırarak güçlükleri yenmesi, en az kısıtlayıcı ortamda bulunması, var olan durumunu benimsemesi ve ilgi/ yeteneklerinin farkına varmasını sağlayacak uygun bir ortamın hazırlanmasıdır. Ayrıca çocukların çevresinde dışlanan değil benimsenen duruma gelmesi, sınıfın bir üyesi haline gelmesi, sağlıklı öğrencilerin katıldığı tüm etkinliklere katılmasını sağlamak da kaynaştırma eğitiminin amaçlarındandır. ${ }^{[12]}$

Kaynaştırma eğitimi Finlandiya, İngiltere, Amerika Birleşik Devletleri, Almanya, Hindistan ve Avustralya gibi pek çok ülkede uygulanmaktadır ve uygun koşullar sağlandığında başarılı olduğu bilinmektedir. ${ }^{[9]}$ Kaynaştırma eğitiminin başarılı olabilmesi için, sınıf mevcudunun uygunluğu (en fazla 20 kişi), eğitim materyallerinin yeterliliği, öğretmen ve idarenin tutumu, akranların yaklaşımı, ekonomik kaynaklar ve hizmet içi eğitimler önemlidir. ${ }^{[13,14]}$ Kaynaştırma eğitiminin özel bakım gereksinimli çocuğa; sağlıklı akranları ile iletişime geçme, sosyalleşme, işbirliği yapma, olumlu davranışları model alma gibi katkıları bulunmaktadır ${ }^{[8]}$ Kaynaştırma eğitiminin özel bakım gereksinimli çocuğa olumlu katkılarının yanında, aileye, sağlıklı akranlarına ve öğretmenlerine de katkıları vardır. Ailelerin toplumdan soyutlanma hissinin azalmasını, çocuklarındaki gelişimi fark etmelerini ve kaygı düzeylerinin azalmasını sağlayabilmektedir. Çocuğun sağlıklı akranlarına; sorumluluk alma, yardım etme, iletişimi geliştirme becerileri kazandırabilmektedir. Öğretmenlere; öğrenciler arasında eşitliğe, sabır, hoşgörü ve deneyimleri artırma gibi faydası olduğu bilinmektedir. ${ }^{[3,15,16]}$

\section{Özel Bakım Gereksinimli Çocuklar ve Ailelerin Kaynaştırma Eğitiminde Yaşadığı Sorunlar}

Kaynaştırma eğitimi, özel bakım gereksinimli çocuklar için sadece eğitim- öğretime devam etme hakkı değildir. Kaynaştırma, arkadaş, okul ya da etkinlik grubu gibi bir topluluğa ait olmakla ilgili olabilmektir. Kaynaştırma eğitiminde özel bakım gereksinimli çocukların eğitim gereksinimlerinin yanında diğer gereksinimlerinin de karşılandığı bir eğitim ortamı sağlanmalıdır. ${ }^{[10,17]}$ Okullarda kaynaştırma eğitimi uygulanmasına, her çocuğun bireysel özellikleri dikkate alınarak ve çocuğun özgün ihtiyaçları karşılandıktan sonra başlanmasının önemi vurgulanmaktadır. ${ }^{[18,19]}$ Çocuğun özgün gereksinimlerinin yanında, okulun fiziki yapısı, malzemelerin yeterliliği, öğretmen sayısı, sağlık persone- 
line ulaşım, öğretmen ve idarenin tutumu, aile ve öğretmenin iletişimi de önem taşımaktadır. ${ }^{[20]}$ Ayrıca kaynaştırma eğitimine başlamadan önce ve eğitim süresince aile ve öğretmenler sürekli iletişim ve işbirliği içerisinde olmalıdır. Çünkü aile ve öğretmenlerin eğitim açısından ortak beklentiler geliştirmeleri, çocukların bu beklentileri daha kolay yerine getirebilmeleri için önemlidir. ${ }^{[21]}$ Bu durumda, çocukların okul başarılarının arttığı, olumlu okul deneyimleri kazanıldığı, ev ile okul ortamı arasındaki kültürel veya davranışsal farklııkların azaldığı belirtilmiştir. ${ }^{[2]}$

Her çocuk ve aileye bireysel hazırlanmayan ve uygun koşullarda yapılmayan kaynaştırma eğitiminde, çocuk ve ailenin gereksinimlerinin yetersiz karşılanmasına ya da hiç karşılanmamasına bağlı sorunlar yaşanabilmektedir. Bu bölüm özel bakım gereksinimli çocukların yaşadıkları 1) Fiziksel gereksinimlere yönelik sorunlar, 2) Duygusal ve Psiko-sosyal gereksinimlere yönelik sorunlar ve 3) Ailelerin gereksinimlerine yönelik sorunlar olarak üç bölümde ele alınmıştır (Şekil 1).

\section{Fiziksel Gereksinimlere Yönelik Sorunlar}

Özel bakım gereksinimli çocuklar, boşaltım gereksinimini giderme, hareket gereksinimini karşılayabilme, okula ulaşımı sağlama, merdiven çıkabilme, günlük kullanması gereken ilaçları kullanabilme gibi konularda destek/yardıma intiyaç duyabilirler. Bu çocukların fiziksel gereksinimlerinin birçoğunu okulda yardımsız karşılayabilmeleri güç olabilmektedir. Gereksinimleri karşılanamayan özel bakım gereksinimli çocuklar okula devam etmekte isteksiz olabilmektedir. ${ }^{[23,24]}$ Clark ve MacArthur (2008), çalışmalarında özel bakım gereksinimli çocukların okulda kendi kendine spor aktivitelerine katılamadıklarını, okul gezi ve kamplarına gidemediğini, oyun oynayamadığını belirtilmişlerdir. ${ }^{[25]} \mathrm{Bu}$ durumlarda çocuğun ailesi/annesi çocuğun beslenmesini sağlayabilmek, ilaçlarını uygulayabilmek, kazalara müdahale edebilmek gibi gereksinimlerini karşılamak için sürekli olarak okulda beklemek zorunda kalabilmektedir.

\section{Duygusal, Psikososyal gereksinimlere yönelik sorunlar}

Özel bakım gereksinimli çocuklar arkadaşları ve öğretmenleri ile iletişim kurma, okuldaki sosyal aktivitelere katılma ve akran-

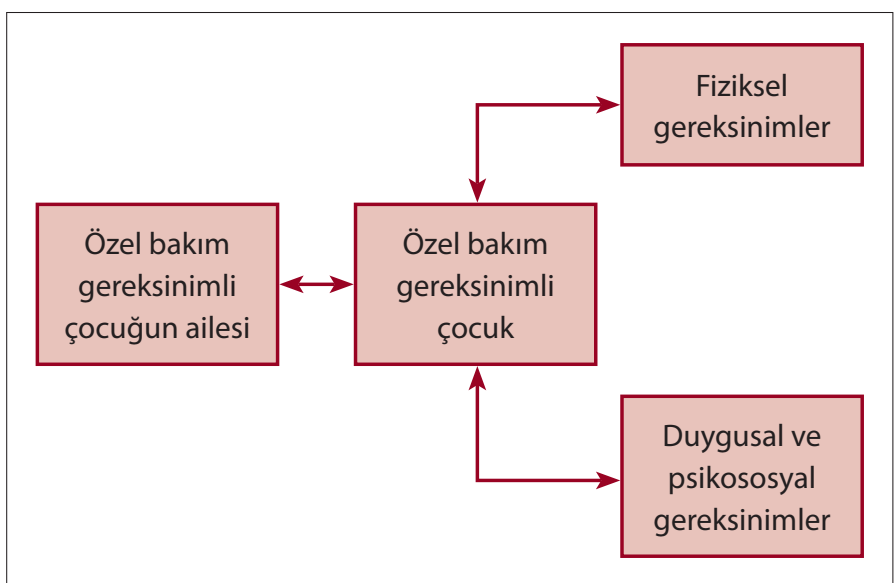

Şekil 1. Özel bakım gereksinimli çocuk ve ailelerinin gereksinimleri. ları ile vakit geçirme gibi konularda güçlük çekebilmektedir. [26,27] Özel bakım gereksinimli çocuklar okulda sağlıklı gelişim gösteren arkadaşları tarafından dışlanma, alay edilme, veliler tarafından sınıfta istenmeme gibi sorunlar yaşamaktadır. ${ }^{[14]}$ Kabasakal ve arkadaşları (2008), çalışmalarında kaynaştırma öğrencilerinin \%68.8 oranında fiziksel şiddet, \%25 oranında sözel şiddet gördüklerini ve kaynaştırma öğrencilerinin daha az sevilen ve arkadaşlarılya iletişim problemleri olan grup olduğunu saptamışlardır. ${ }^{[28]}$ Sosyal kabul göremeyen bu çocukların akademik başarıları da olumsuz etkilenmektedir. Girli ve Atasoy (2012), çalışmalarında kaynaştırma eğitimindeki öğrencilerin özellikle oyunlarda dışlandıklarını ve kendilerini yalnız hissettiklerini, derslerde akademik başarılarının düşük olduğunu belirtmişlerdir. ${ }^{[29]}$ Duygusal ve psikososyal gereksinimlerini yeterince karşılayamayan çocuklar kendilerini yalnız hissedebilmektedir ve duygularını yeterince ifade etmeyebilmektedirler. Böyle durumlarda özel bakım gereksinimli çocukların aileleri çocuklarının yaşantısında önemli bir yer almaktadır ve çocukların sosyal desteğini aileler oluşturmaktadır. ${ }^{[30]}$

\section{Ailelerin gereksinimlerine yönelik sorunlar}

Ailede özel bakım gereksinimli çocuğun olması, ailelerin bakım yükünü artırmakta, ekonomik sıkıntılara yol açabilmekte, kaygı ve stres düzeyleri artırmaktadır. ${ }^{[31-33]}$ Busch ve Barry (2007), çalışmalarında engelli çocuğa sahip ailelerin sağılıkı çocuğa sahip ailelere göre haftada dört saatten fazla zamanlarını çocuklarının bakımı için harcadığını belirtmişlerdir. ${ }^{[34]}$ Buran ve arkadaşları (2009), çalışmalarında ailelerin dinlenme/ eğlence, çocuk bakımı, hastalık tedavi ve bakımları konusunda bilgi gereksinimleri olduğunu saptamışlardır. ${ }^{[35]}$

Kaynaştırma eğitimine devam eden çocuklarının ailelerinin bakım sorumlulukları çocuk okulda olduğu sürede de devam etmektedir. Aileler çocuğun beslenme, boşaltım, hareket gibi fiziksel gereksinimlerini okulda da karşılanmak durumundadır. ${ }^{[24]}$ Çocuklarının psikososyal gereksinimlerini belirlemek ve karşılamakta da ne yazık ki ailelerin sorumluluğundadır. Aileler için çocuğun arkadaşları ve öğretmenleri ile iletişime geçmesi, fiziksel ve sözel şiddete maruz kalmaması önemlidir. ${ }^{[14]}$ Pinquart ve Pfeiffer (2011), çalışmalarında görme engeli olan çocukların arkadaş edinme ve kazanmada başarısız olduklarını, fiziksel ve sözel şiddete maruz kaldıklarını ve aileleri tarafından aşııı korunduklarını belirtmişlerdir. ${ }^{[36]}$ Özel bakım gereksinimli çocukla okulda ilgilenmesi için bakım vericiye ihtiyaç olabilmektedir. Okul sağlığı hemşiresi bulunmayan okullarda özel bakım gereksinimli çocukların bakımlarını okulda da aileleri üstlenmektedir. Bu durum ailelerin çeşitli sorunlar yaşamasına yol açmaktadır. Anderson (2009), çalışmada annelerin okul personeli ve sağlık çalışanları ile iletişim sorunları yaşadıklarını, eğitim sistemi ile mücadele ettiklerini, okulda bakıcı olarak primer sorumluluğun annede olduğunu, çocuklarının durumu ile ilgili sorunlarla başa çıkmak zorunda kaldıklarını saptamış$\operatorname{tir}^{[37]}$

Okulda ve evde sürekli çocukların bakım sorumluluğunu üstlenme, ailelerin sosyal aktivitelere katılmalarını, ailenin diğer 
bireyleri ile zaman geçirmelerini ve çalışan anne babaların işlerine devam etmelerini engellenmektedir. ${ }^{[31-33]}$ Bu durumda ailelerinde danışmanlık ve eğitime gereksinimleri olabilmektedir.

\section{Kaynaştırma Eğitimi Alan Çocuklarda Okul Sağlığı Hemşiresinin Rolleri}

Özel bakım gereksinimli çocuğun ailesi, çocuk okula başlamadan önce ve okula devam ettiği sürece birçok konuda eğitim ve desteğe gereksinim duymaktadır. ${ }^{[30]}$ Okul çağı çocuklar için çok önemli bir dönemdir, çocukların birçoğu için okul, kendi evleri dışında toplu olarak bulundukları ilk yerdir. Okul, çocuklar için akademik başarıyı yakalamak, sağlıklı yaşam alışkanlıkları ve yetenekleri kazandırmak için temel kurumdur. Eğer bu dönemde çocuğa iyi bir sağlık bilgisi öğretilir ve sağlıkla ilgili doğru davranışlar kazandırılırsa sağlık konusunda bilinçli bir toplum oluşturulabilir. ${ }^{[38]}$ Okullarda sağlık hizmetleri sunucuları, çocuklarda sağlık problemlerini çözmede ve sağlığı geliştirmede çok önemli rol oynamaktadır ${ }^{[39]}$ Kaynaştırma eğitimi alan öğrenciler gününün $1 / 3^{\prime}$ ünü okulda sosyal bir çevrenin etkisi altında geçirmektedir. ${ }^{[40,41]}$ Bu nedenle okulda çocuğun gereksinimlerinin karşılanması önemlidir. Okul sağlığı hemşiresi özel bakım gereksinimi olan çocuk ve ailesiyle çalışırken, bakım verici, eğitici, araştırıcı, danışmanlık, karar verici, koruyucu, gözetleyici ve savunucu rollerinin tamamını uygulamalıdır. ${ }^{[42]}$ Bu bölümde kaynaştırma eğitimi alan çocuklarda okul sağlığı hemşiresinin rolleri dört bölümde ele alınmıştır. Bunlar; 1) Fiziksel gereksinimlerine yönelik rolleri, 2) Psikososyal gereksinimlerine yönelik rolleri, 3) Ailelerin yaşadıkları sorunlara yönelik rolleri ve 4) Okul ve öğretmenlerin yaşadıkları sorunlara yönelik rolleridir.

\section{Okul Sağlığı Hemşiresinin Özel Bakım Gereksinimli Çocuklarda Fiziksel Gereksinimlere Yönelik Rolleri}

Okul sağlığı hemşiresi, kaynaştırma eğitimine devam eden bu çocukların fiziksel bakımında, çocuğun, büyüme ve gelişmelerini izleme, beslenme, boşaltım, solunum, hareket gereksinimi, ilaçların kullanımı, akut veya kronik sağlık sorunlarına müdahale, kaza ve yaralanmalara müdahalelere yönelik hemşirelik girişimleri planlamalı ve uygulamalıdır (Tablo 1).

Okul sağlığı hemşiresi özel bakım gereksinimli çocukların yeterli ve dengeli beslenmeleri konusunda yardımcı olmalıdır. Özel bir diyeti olan çocukların okulda diyetine uygun beslenmesini sağlamalıdır. Okul yemekleri ve varsa kantinde satılan yiyeceklerin çocuğun diyetine uygunluğunu değerlendirmeli ve bu konuda çocuk, aile ve okul çalışanlarını bilgilendirmelidir. Hemşire çocuğun ana ve ara öğünleri zamanında alması konusunda desteklemelidir. Beslenmede destek gereksinimi olan çocuklarda beslenmeye yardımcı olmalıdır. Ağızdan sıvı akması gibi durumlarda kıyafetlerin kuru kalması için aileye danışmanlık yapmalıdır. ${ }^{[43]}$

Okul sağlığı hemşiresi, okulda özel bakım gereksinimli çocuğun gereksinimlerine uygun tuvalet ve lavabo bulunmasında sorumludur. Çocukta enürezis ve/veya enkoprezis problemi yaşanıyorsa çocuk yakından izlenmeli ve gerekli önlem ve bakımları yapmalıdır. ${ }^{[43]}$ Okul sağlığı hemşiresi solunum sistemi sorunu olan çocukların bakımında ortamın uygun havalandırması ve varsa acil ilaçlarının kullanılmasını sağlamalıdır. Örneğin, astım tanısı olan çocukta acil ilaçlarının yanında olması ve hemşire dışında çocuğun sürekli yanında bulunan öğretmen, arkadaş gibi kişilerin bu konuda bilgi-

Tablo 1. Kaynaştırma eğitimi alan özel bakım gereksinimli çocuklarda okul sağlığı hemşiresinin rolleri

Özel bakım gereksinimli çocuklara yönelik roller

Özel bakım gereksinimli çocuk ailelerine yönelik roller

Özel bakım gereksinimli çocukların okul ve öğretmenlerine yönelik roller
Fiziksel gereksinimlere yönelik;

- Büyüme ve gelişmelerini izleme,

- Beslenme,

- Boşaltım,

- Solunum,

- Hareket gereksinimi,

- İlaçların kullanımı,

- Akut veya kronik sağlık sorunlarına müdahale,

- Kaza ve yaralanmalara müdahale.

Duygusal ve psiko-sosyal gereksinimlere yönelik;

- Danışmanlık hizmetleri verilmesi,

- Aile ile işbirliği kurma,

- Olumlu sağlık davranışlarının kazandırma,

- Sağlık eğitimi verme,

- Akademik başarılarının artırılması,

- İyi bir savunucu olma ve etik ilkelere göre karar verme.

- Aile ve okul arasında işbirliği sağlama,

- Özel bakım gereksinimi olan çocuk hakkında sağıı danışmanlığı yapma,

- Okul sağlığı hizmetleri ile ilgili sorunları ve gereksinimleri saptama,

- Öğrenci-öğretmen arasında işbirliği sağlama. 
lendirmesini sağlamalıdır. Okul sağlığı hemşiresi özel bakım gereksimli çocuğun hareket gereksinimini karşılanması için okul ve çevre düzenini öğrencinin rahat hareket edebileceği özel asansör ve yürüyüş rampası sağlanması konusunda okul yönetimiyle işbirliği yapmalıdır. Ayrıca hareket kısıtlılığı olan çocuklarda konstipasyon görülme riskine karşı ebeveynlere danışmanlık yapmalıdır. ${ }^{[42,44-47]}$ Çocukların ilaçlarının okulda uygulaması hemşirenin sorumluluğundadır. Hemşire ilaçların doğru kullanımını sağlamak için ailelerin eğitimini sağlamalı ve ilaçların yan etkilerine karşı önlemler almalıdır. Okul sağlığı hemşiresi özel bakım gereksinimli çocuklarda akut/ kronik sağlık sorunları ve kazalar ile karşılaştığında müdahale etmelidir. ${ }^{[42-48]}$

Hemşire çocuğun fiziksel bakımı konusunda çocuğa, ailesine eğitimler ve danışmanlık hizmetleri vermelidir. Bu eğitimler çocuğun yaşına ve gereksinimlerine uygun olarak düzenlenmelidir. Eğitimler büyüme gelişme, aşılar, maddenin kötüye kullanımı, adet kanaması/mensturasyon yönetimi, cinsellik, üreme sağlığı, istismar riski, güvenlik ve ruhsal değişiklikler gibi konuları içermelidir. ${ }^{[43]}$ Okul hemşiresi, eğitim, danışmanlık ve iletişim becerileri ve özel bakım gereksinimi olan çocuk ve ailesinin gereksinimlerini konularında bilgi ve deneyim sahibi olmalıdır.

\section{Okul Sağlığı Hemşiresinin Özel Bakım Gereksinimli Çocuklarda Duygusal ve Psiko-Sosyal Gereksinimlerine Yönelik Rolleri}

Okul sağlığı hemşiresi, kaynaştırma eğitimine devam eden çocukların duygusal ve psikososyal bakımında, danışmanlık hizmetleri verme, aile ile işbirliği kurma, olumlu sağlık davranışlarının kazandırma, sağlık eğitimi verme, akademik başarılarının arttırma, iyi bir savunucu olma ve etik ilkelere göre karar vermeye yönelik hemşirelik girişimleri planlamalı ve uygulamalıdır (Tablo 1).

Okul sağlığı hemşiresi özel bakım gereksinimli çocuklarda görülen davranış ve uyum problemlerini değerlendirmeli ve problemin nedenlerini araştırıp çözüm yollarını aile-okul ile belirleyip sağlık profesyonellerinden destek alarak çözüm sağlamalıdır. Bu çocukların birçoğu okulda dışlanmakta ve psikolojik ve fizyolojik şiddete uğramaktadır. Böyle durumlarda kaynaştırma eğitimi alan öğrenciler kendilerini ifade etmekte zorlanmakta, okul eğitimine devam etmek güç olabilmektedir. ${ }^{[14]}$ Özel bakım gereksinimli çocukların durumları hakkında, sağlıklı akranlarına bilgilendirme yapmalıdır. Bu durum çocuğun sınıfta ve okulda kabulünü arttıracaktır. Okul sağlığı hemşiresi bu çocuklar için iyi bir savunucu olmalı ve istismar bulgularını gözlemlemeli, etik ilkelere göre karar vermelidir.

Okul sağlığı hemşiresi özel bakım gereksinimli çocukların aileleri ve sağlıklı çocukların aileleri ile işbirliği yapmasında yol gösterici olmalıdır ve bu çocukların akademik başarılarının artırılması için öğretmenler ile işbirliği yapmalıdır. Ayrıca okul sağlığı hemşiresi özel bakım gereksinimli çocuklara yönelik politikaların belirlenmesine katkı sağlamalıdır. ${ }^{[44,47,49-51]}$

\section{Okul Sağlığı Hemşiresinin Özel Bakım Gereksinimli Çocukların Ailelerinin Yaşadığı Sorunlara Yönelik Rolleri}

Okul sağlığı hemşiresi, kaynaştırma eğitimine devam eden bu çocukların ailelerinin yaşadığı sorunlara yönelik bakım, aile ve okul arasında işbirliği sağlama, özel bakım gereksinimi olan çocuk hakkında sağlık danışmanlığı yapmaya yönelik hemşirelik girişimleri planlamalı ve uygulamalıdır (Tablo 1).

Kaynaştırma eğitimi alan özel bakım gereksinimli çocukların aileleri, zamanlarının çoğunu okulda çocuklarının gereksinimlerini karşılamak için geçirmektedir. Bu durum aileleri zorlamaktadır. Okul sağlığı hemşiresi özel bakım gereksinimli çocukların ihtiyaçlarını karşıladığında, ailelerin okulda beklediği süre azalacaktır. ${ }^{[38]}$ Okul sağlığı hemşiresi özel bakım gereksinimli çocuklarının fiziksel bakımı, sosyal uyumu, özgüven geliştirilmesi gibi konularda ailelere eğitim ve danışmanlık hizmeti sağlamalıdır. Yapılan çalışmalarda, özel bakım gereksinimli çocuk ve aileye yapılan eğitim ve danışmanlığın ailelerin kaygı ve stresini azalttığı ve yaşam kalitesini arttırdığı belirlenmiş̧ir. Tsai ve Wang (2009), okul çağındaki zihinsel engelli çocukların bakımında zorlanma ve sosyal destek alma arasındaki ilişkiyi incelediği çalışmalarında, ailelerin yaşam kalitesini artırmak için sağlık profesyonellerinin destek olması gerektiği vurgulamışlardır. ${ }^{[2]}$

\section{Okul Sağlığı Hemşiresinin Özel Bakım Gereksinimli Çocukların Okul ve Öğretmenlerinin Yaşadığı Sorunlarına Yönelik Rolleri}

Okul sağlığı hemşiresi kaynaştırma eğitimine devam eden bu çocukların, okul sağlığı hizmetleri ile ilgili sorunları ve gereksinimleri saptama, öğrenci-öğretmen/okul yönetimi ve çalışanları arasında işbirliği sağlamaya yönelik yönelik hemşirelik girişimleri planlamalı ve uygulamalıdır (Tablo 1). Ryan (2008), okul hemşiresinin öğrenci ve okul personelinin sağlığını geliştirmedeki rolünü incelediği çalışmasında, hemşirenin sağlık gereksinimlerini belirlemede, okulda sağlığı geliştirme programları oluşturmada, planlamada, uygulamada, değerlendirmede yer aldığını vurgulamıştır. ${ }^{[53]}$

Okul sağlığı hemşiresi çocukların öğretmenleri ve okul yönetimi ile sürekli iletişim halinde bulunmalı ve gereksinimleri karşılayarak okulu özel gereksinimli çocuk için daha çok sevilen bir yer konumuna gelmesini sağlamalıdır. Ayrıca okulun fiziki ortamını değerlendirmeli ve uygun olmayan fiziki ortam düzenlenmelidir. Fiziksel engeli olan çocuklar için özel tuvalet, lavabo boylarının ayarlanması, tutunma barlarının temin edilmesi, engelli rampa ve asansör olması, sınıf tahta ve oturma sıralarının uygun olmasını sağlamalıdır. ${ }^{[38,53,54]}$ Okul sağlığı hemşiresi öğrenci-öğretmen arasında işbirliğini sağlayarak özel bakım gereksinimli çocukların sınıfın bir elamanı olmasını desteklemelidir. ${ }^{[38,50,51]}$ Hill ve Hollis (2012), okul sağlığı hemşiresi bulanan okullarda öğretmenlerin öğrencileri ile sağlık konularında harcadığı vakti incelediği çalışmalarında, öğretmenlerin öğrencilerin sağlık sorunlarından dolayı her gün bir saat harcadıklarını okulda hemşire bulunduğunda öğrencilerin öğrenme zamanının arttığını belirtmişlerdir. ${ }^{[54]}$ 
Sonuç; Kaynaştırma eğitimine devam eden özel bakım gereksinimli çocukların fiziksel, duygusal ve psikososyal gereksimleri sağlıklı akranlarından farklılık göstermektedir. Kaynaştırma eğitiminin çocuk sağlığı üzerinde olumlu katkıları bulunduğu görülmektedir. Ancak çocuklar ve aileler okulda sorunlar yaşayabilmektedir. Okul sağlığı hemşiresi bulunduğunda özel gereksimli çocuk ve ailesinin gereksinimleri zamanında karşılanacak ve görülen sorunlar azalacak ve çocukların okul devamı artacaktır. Kaynaştırma eğitimi alan çocukların okullarında okul sağlığı hemşiresi bulunduğunda çocuklar ve ailelere olumlu katkıları olduğu görülmektedir.

\section{Çıkar çatışması: Bildirilmemiştir.}

\section{Kaynaklar}

1. Bines H, Lei P. Disability and education: The longest road to inclusion. İJEDUDEV 2011;31:419-24.

2. Yaralı D. Öğretmen Adaylarının Özel Eğitim Dersine Yönelik Tutumlarının Bazı Değişkenler Açısından İncelenmesi. PAUSBED 2016;24,59-76.

3. Milli Eğitim Bakanlığı Özel Eğitim Hizmetleri Yönetmeliği 2009. Resmi Gazete: 26184.

4. World report on disability 2011. Son Erişim Tarihi: 22.122016. Elektronik adresi: http://www.who.int/disabilities/world_report/2011/report.pdf

5. Türkiye İstatistik Kurumu Türkiye Özürlüler Araştırması Bülteni 2002. Son Erişim Tarihi: 20.12.2016. Elektronik adresi: http://www. tuik.gov.tr.

6. Eripek S. Özel eğitim ve kaynaştırma uygulamaları. S Eripek, Editör. Illköğretimde Kaynaştırma Uygulamaları. Anadolu Üniversitesi Açık öğretim Fakültesi Yayınları: Eskişehir; 2007. s. 1-21.

7. Koster M, Nakken H, Jan Pijl S, Van Houten E. Being Part Of The Peer Group: A literature study focusing on the social dimension of inclusion in education. International Journal Of Inclusive Education 2009;13:117-40.

8. Reed FD, Mcıntyre LL, Dusek J, Quintero N. Preliminary assessment of friendship, problem behavior, and social adjustment in children with disabilities in an inclusive education setting. J Dev Phys Disabil 2011;23:477-89.

9. Friend M, Cook L, Hurley-Chamberlain D, Shamberger C. Coteaching: An illustration of the complexity of collaboration in special education. J Educ Psychol Cons 2010;20:9-27.

10. Okul öncesi eğitim programı. MEB Yayınları: Ankara; 2013.

11. Mili Eğitim Bakanlığı İstatistikleri 2015-2016. Son Erişim Tarihi: 22.12.2016. Elektronik adresi http://sgb.meb.gov.tr/istatistik

12. Schwab S, Gebhardt M, Krammer M, Gasteiger-Klicpera B. Linking selfrated social inclusion to social behaviour. an empirical study of students with and without special education needs in secondary schools. Eur. J. of Special Needs Education 2015;30:1-14.

13. Fuchs D, Fuchs L. Peer assisted learning strategies: Promoting word recognition, fluency and reading comprehension in young children. The Journal of Special Education 2005;39:34-44.

14. Olcay Gül S, Vuran S. Normal sınıflara devam eden özel gereksinimli öğrencilerin kaynaştırma uygulamasına ilişkin görüşleri ve karşılaştıkları sorunlar. TEDMEM 2015;40:169-95.

15. Terpstra JE, Tamura R. Effective social interaction strategies for inclusive settings. Early Childhood Educ J 2008;35:405-11.

16. Leaf JB, Taubman M, Bloomfield S, et al. Increasing social skills and pro-social behavior for three children diagnosed with autism through the use of a teaching package. RASD 2009;3:275-89.

17. Allen KE, Cowdery GE. The exceptional child: Inclusion In Early Childhood education. Thomson: USA; 2005.

18. Acarlar F. Kaynaştırma modeli ve özel gereksinimli çocukların özellikleri. Kök yayınevi: Ankara; 2013. s. 21-75.

19. Bowe F. Making inclusion work. Pearson: New Jersey; 2005.

20. Özgür G. İlköğretimde kaynaştırma. Karahan yayınevi: Adana; 2011.

21. Lane KL, Stanton-Chapman T, Roorbach JK, Phillips A. Teacher and parent expectations of preschoolers' behavior: social skills necessary for success TESCE. 2007;27:86-97.

22. Beebe-Frankenberger M, Lane KL, Bocian KM, Gresham FM, MacMillan D. L. Students withor at risk for problem behavior: Betwixt and between teacher and parent expectations. Preventing School Failure 2005;49:10-7.

23. UNICEF. Children with disabilties. United Nations Children's Funds. 2013.

24. Girgin Aykanat B, Balc S. Fiziksel engelli çocuk ve ailesinin evde bakım gereksinimi. GÜSBD 2015;4:305-17.

25. Clark P. MacArthur J. Children with physical disability: Gaps in service provision, problems joining in. J Paediatr Child Health 2008;44:455-8.

26. Cavkaytar A. Özel eğitime gereksinim duyan çocuklar ve özel eğitim. Üçüncü basım. Pegem Akademi: Ankara; 2010. s. 3-27.

27. Heward WL. Exceptional children. An Introduction to special education. Ninth edition. Pearson: New Jersey; 2009.

28. Kabasakal Z, Girli A, Okun B, Çelik N, Varlı G. Kaynaştırma öğrencileri, akran ilişkileri ve akran istismarı. Befjournal 2008;(23):169-76.

29. Girli A, Atasoy S. Kaynaştırmaya yerleştirilen zihin yetersizliği veya otistik özellikleri olan öğrencilerin okul yaşantıları ve akranlarıyla ilişkilerine ilişkin görüşleri. Befjournal 2012;(32):16-30.

30. Williams P. The role of the social worker with people with learning difficulties. Parkerand J. Bradley G. editors. Social work with people with learning difficulties. byBell \&BainLtd: Glasgow; 2009. p. 36-57.

31. Oh H, Lee EO. Care giver burden and social support among mothers raising children with developmental disabilities in South Korea. IJDDE 2009;56:149-67.

32. Xiong N, Yang L, Yu Y, Hou J, Li J, Li Y, et al. Investigation of raising burden of children with autism, physical disability and mental disability in china. Res Dev Disabil 2011;32:306-11.

33. Kaytez N, Durualp E, Kadan G. Engelli çocuğu olan ailelerin gereksinimlerinin ve stres düzeylerinin incelenmesi. JRET 2015;4:197-214.

34. Busch SH, Barry CL. Mental health disorders in childhood:assessing the burden on families. Health Aff 2007;26:1088-95.

35. Buran CF, Sawin K, Grayson P, Criss S. Family needs assessment in cerebral palsy clinic. JSPN 2009;14:87-93.

36. Pinquart M, Pfeiffer JP. Associations of extroversion and parental overprotection with forming relationships with peers among ado- 
lescents with and without visual impairments. JVIB 2011;105:96107.

37. Anderson SL. Mothers of childrenwith special health care needs: documenting the experience of their children's care in the school setting. J Sch Nurs 2009;25:342-51.

38. National Association of School Nurses. School-Nursing-Scopeand-Standards 2011. Son erişim tarihi: 23.12.2016. Elektronik adresi: www.nasn.org

39. National Association of School Nurses. School-Nursing-Scopeand-Standards 2008. Son erişim tarihi: 21.12.2016. Elektronik adresi:www.nasn.org.

40. Nies MA, McEwen M. Community/Public Health Nursing Promoting the Health of Populations, School Health. Fifth edition. Elsevier: Missouri; 2011. p. 584-601.

41. Güler Ç, Akın L. Okul sağlığı halk sağlığı temel bilgiler. Hacettepe Yayınları: Ankara; 2012. s. 441-83.

42. Hemşirelik Yönetmeliğinde Değişiklik Yapılmasına Dair Yönetmelik 2011. T.C. Resmi Gazete 27910.

43. Altay N. Özel gereksinimi olan çocuklarda akut ve kronik sağlık sorunları. Yanardağ M, Yılmaz İ. edititörler. Sağlık ve ilk yardım. Pegem akademi: Ankara; 2017.

44. Magalnick $H$, Mazyck D. Role of the school nurse in providing school health services. Pediatrics 2008;121:1052-6.

45. Wang YL, Volker DL.(2013). Caring for Students With Type 1 Dia- betes: School Nurses' Experiences. J Sch Nurs 29(1):31-8.

46. Koçoğlu D, Emiroğlu ON. Okul hemşiresinin okul sağlık tarama programlarındaki rolünün değerlendirilmesi. HEMAR-G. 2011;3:519.

47. Kumar S, Sharma J, Duraiswamy P, Kulkarni S. Determinants for oral hygiene and periontalstatus among mentally disabled children and adolescent. J İndian Soc Pedod Prev Dent 2008;27:1517.

48. Tabak RS, Somyürek Hi. Hemşireler için temel ilk yardım ve acil bakım. Palme yayıncılık: Ankara; 2008.

49. Adana F, Arslantaş H. Ergenlikte öfke ve öfkenin yönetiminde okul hemşiresinin rolü. ADÜ Tıp Fakültesi Dergisi 2011;12:57-62.

50. Puskar KR, Bernardo LM. Mental health and academic achievement: Role of school nurses. J Spec Pediatr Nurs 2007;12:215-23.

51. Nayır F, Karaman-Kepenekçi Y. Kaynaştırma öğrencilerinin haklarına ilişkin sınıf öğretmenlerinin görüşleri. EBAD JESR 2013;3:6989.

52. Tsai SM, Wang HH. The relation ship between caregiver's strain and social support among mothers within tell ectually disabled children. J Clin Nurs 2009;18:539-48.

53. Ryan K. Health promotion of faculty and staff: The school nurses role. J Sch Nurs 2008;24:183-9.

54. Hill NJ, Hollis M. Teacher time spent on student health issues and school nurse presence. J Sch Nurs 2012;28:181-6. 